\title{
The Impact of Corporate Governance on Dividend Payout of Manufacturing Firms Listed at the Nairobi Securities Exchange
}

\author{
Caroline Ikunda, Monica Muiru, Simon M Kamau \\ Faculty of Commerce, Department of Accounting, Finance \& Management Science, Egerton University, Nakuru, Kenya
}

Email address:

c.ikunda@yahoo.com (C. Ikunda), mshirom@yahoo.com (M. Muiru), Simonms.99@gmail.com (S. M Kamau)

To cite this article:

Caroline Ikunda, Monica Muiru, Simon M Kamau. The Impact of Corporate Governance on Dividend Payout of Manufacturing Firms Listed at the Nairobi Securities Exchange. Journal of Finance and Accounting. Vol. 4, No. 5, 2016, pp. 254-261. doi: 10.11648/j.jfa.20160405.12

Received: May 31, 2016; Accepted: June 12, 2016; Published: August 29, 2016

\begin{abstract}
This study sought to examine the impact of corporate governance on dividend payout of manufacturing firms listed at the NSE. The objectives of the study were; to determine the impact of board size, board composition, CEO tenure and managerial equity holding on dividend payout of manufacturing firms listed at NSE and finally, to establish the impact of corporate governance on dividend payout of manufacturing firms listed at NSE. The study employed a correlational research design and the population of the study comprised all manufacturing firms which were consistently listed at the Nairobi Securities Exchange from 2008-2014. Correlation and regression analysis were used to test the impact of the independent variables relating to corporate governance practices on the dependent variable (Dividend Payout). Independent one-way ANOVA test and independent t-test (one tailed) were used to determine the level of significance. The study found that board size, board composition, CEO tenure and management equity holding have a weak negative relationship with dividend payout. Further, the study found that board size has a statistical significant impact on dividend payout, while board composition, CEO tenure and managerial equity holding were found to have no statistical significant impact on the dividend payout. The empirical results from the multiple regression analysis indicated that there is a strong positive relationship between corporate governance and dividend payout. However, there was no statistical significant relationship between the two variables. Therefore, this study concludes that corporate governance has no impact on dividend payout of manufacturing firms listed at NSE.
\end{abstract}

Keywords: Corporate Governance, Dividend Payout, Manufacturing Firms, Nairobi Securities Exchange

\section{Introduction}

Corporate Governance is defined as the process and structure used to direct and manage business affairs of a company with the ultimate objective of realizing shareholder long-term value while taking into account the interest of other stakeholders. Corporate Governance is acknowledged to play an important role in the management of organizations in both developed and developing countries (Achchuthan and Kajananthan, 2013). It aims at protecting the interests of shareholders and improving performance of organizations. According to Chung et al (2010), firms having weaker governance structures face more agency problems and this increases the risk to shareholders. This is due to lack of proper structures, mechanisms and processes that ensure that a firm is managed and directed in a way that ensures increase in shareholder value. As a result, corporate governance becomes an important aspect of enhancing the performance of organization by increasing management accountability.

Hifzalnam and Mukhtar (2014), note that, corporate governance combines a set of market instruments that motivate managers to maximize the value of a firm on behalf of its shareholders. This is by providing processes and structures that are used to direct and manage the affairs of a business thereby enhancing performance and corporate accounting as well as increasing long-term shareholders value. Valenti at el (2011) affirms that corporate governance is essential in improving the performance of organizations. This is because it ensures that the interests of the shareholders are safeguarded, by making sure that the assets of an organization are utilized in a way that maximizes 
profitability. Therefore, corporate governance augments the performance of a company by motivating managers to take actions that maximize the wealth of shareholders.

According to Murekefu and Ouma (2010), shareholders wealth can also be enhanced by a firms dividend policy. This is because the amount that a company is required to distribute to its shareholders is determined by its dividend policy. Ross at el (2002) notes that dividend policy decision is one of the most important decision areas in finance. Dividend decisions are important because they determine the amount of funds that flow to investors and the amount of funds that are retained in a firm for investment purposes. Gul at el (2012), stress that dividend policy decision is important in organizations because it enables them to achieve efficient performance and to attain their goals.

The ultimate goal of a firm is to maximize the wealth of shareholders (Griffin, 2010). Accordingly, managers are compelled to provide shareholders with good returns on their investment. Vojtech (2013) notes that efficient corporate governance can provide checks and balances between managers and shareholders and this can make firms to adopt dividend policies that maximize shareholders wealth. Sheikh and Wang (2010) state that corporate governance is aimed at protecting the interests of shareholders by reducing the agency problems and therefore, dividend policy becomes an important aspect of corporate governance.

\subsection{Statement of the Problem}

The aim of corporate governance is to encourage investment by protecting and maintaining the interests and the rights of the shareholders (Ongore and K'Obonyo, 2011). Indeed, it is recognized to play an important role in mitigating the problems associated with the agency problem as well as increasing shareholders wealth. According to Gul at el (2012), one way of reducing the agency problems and increasing shareholders wealth is through dividend payout. This is because dividend payout facilitates monitoring of the firms activities and performance by the primary market (Griffin, 2010). This makes dividend payout decisions to be an important component of corporate governance. The existing studies provide conflicting results on the relationship between corporate governance and dividend payout. For instance, studies by Hassan (2010) and Adjaoud and Amar (2011), show that corporate governance has a positive and a statistically significant effect on dividend payout, while Hamdouni (2012) finds a negative and insignificant relationship between corporate governance and dividend payout. On the other hand, studies by Abdel-Halim and Bino (2007), and Ajanthan (2013) indicate that there is no statistical significant relationship between dividend payout and corporate governance. Therefore, owing to these conflicting results, and scarce local literature, this study is aimed at filling this gap identified, by investigating the impact of corporate governance on the dividend payout of manufacturing firms listed at the Nairobi Securities exchange (NSE).

\subsection{Main Objective}

To establish the impact of corporate governance on dividend payout of manufacturing firms listed at the NSE.

\subsection{Specific Objectives}

i. To determine the impact of board size on dividend payout of manufacturing firms listed at NSE

ii. To determine the impact of board composition on dividend payout of manufacturing firms listed at the NSE

iii. To determine the impact of CEO tenure on dividend payout of manufacturing firms listed at the NSE

iv. To determine the impact of managerial equity holding on dividend payout of manufacturing firms listed at the NSE

\subsection{Research Hypothesis}

$\mathrm{Ho}_{1}$ : Board size has no statistical significant impact on dividend payout of manufacturing firms listed at NSE

$\mathrm{Ho}_{2}$ : Board composition has no statistical significant impact on dividend payout of manufacturing firms listed at NSE

$\mathrm{Ho}_{3}$ : CEO tenure has no statistical significant impact on dividend payout of manufacturing firms listed at NSE

$\mathrm{Ho}_{4}$ : Management Equity holding has no statistical significant impact on dividend payout of manufacturing firms listed at NSE

$\mathrm{H}_{05}$ : Corporate governance has no statistical significant impact on dividend payout of manufacturing firms listed at NSE

\section{Literature Review}

\subsection{Theoretical Review}

\subsubsection{The Agency Theory}

Agency theory identifies the agency relationship where one party (the principal), delegates work to another party (the agent). As such, shareholders are the principals, in whose interest the corporation should be run, even though they rely on others for the actual running of the corporation (agents) (Rani and Mishra, 2008). The central problem in corporate governance is to construct rules and incentives to effectively align the behavior of managers (agents) with the desires of principals (owners) since the owners are the residual risk bearers. Yocam and Choi (2010), state that, conflict arises when self-interested directors and managers appropriate value to themselves and therefore the agency theory is about resolving this conflict.

\subsubsection{The Stakeholder Theory}

Rani and Mishra (2008) view a firm as a system of stakeholders that provide the necessary legal and market infrastructure for the firm's activities and therefore the sole purpose of the firm is to create wealth for these stakeholders. These stakeholders include employees, the government, 
suppliers and customers. Corporate governance should refer to the design of institutions to make managers internalize all stakeholders' welfare. Other parties, who have interests in the firm's long-term success, should be taken into account when a firm's objective function is defined (Vives, 2000). Further, Yusoff and Alhaji (2012) stipulate that a corporate entity should seek to provide a balance between the interests of its diverse stakeholders in order to ensure that each interest constituency receives some degree of satisfaction.

\subsection{Corporate Governance}

Corporate governance is defined by Mayer (2007) as a way of bringing the interests of investors and managers in line and ensuring that firms are run for the benefit of investors. Metrick and Ishil (2002) view corporate governance from the investors' perspective as a promise to repay a fair return on capital invested and the commitment to operate a firm efficiently given investments. The existence of divergent and sometimes conflicting objectives among corporate managers and shareholders has given rise to the need for corporate governance, as it primarily aims at finding a solution to the principal-agent problem. Corporate governance practices can vary widely even among firms in the same country operating under the same legal regulations.

\subsubsection{Size of the Board}

Board size refers to the number of directors in the board. It is an important factor to determine the effectiveness of the board. According to Hamdouni (2012), a bigger size board of directors might improve the companies' board effectiveness and support the management in reducing agency cost that resulted from poor management and consequently leads to better financial results. Dalton at el (2009) argue that larger boards are more likely to be associated with an increase in board diversity, in terms of experience, skills, gender and nationality, unlike smaller boards that lack the advantage of having the spread of expert advice and opinion. However, Raheja (2005) showed that larger boards have higher coordination costs, in that, planning, work coordination, decision-making and holding regular meetings can be difficult with a large number of board members. More so, when boards consist of too many members, agency problems may increase, and often it moves into a more symbolic role, rather than fulfilling its intended function as part of the management. Raheja further argues that, smaller boards reduce the possibility of free riding by individual directors and thus increase their decision-making processes.

\subsubsection{Board Composition}

An independent board is generally composed of members who have no ties to the firm in any way. Therefore, there is no or minimum chance of having a conflict of interest because independent directors have no material interests in a company. Dalton et al (2009) state that independent directors are important because inside directors may have no access to external information and resources that are enjoyed by the firm's outside or independent directors. Moreover, for advice or counsel, inside directors are available to the CEO as a function of their employment with the firm; their appointment to the board is not necessary for fulfillment of this function. According to agency theory, a larger proportion of independent directors generally provide better firm performance (Ramdani and Van, 2009).

\subsubsection{CEO Tenure}

It is the decision of the board about hiring and firing a CEO and their proper remuneration have an important bearing on the value of a firm. According to Wanyonyi and Olweny (2013), CEOs are hired on short-term contracts and are more concerned about the performance of the firm during their own tenure causing them to lay emphasis on short and medium-term goals. Heinrich (2002) proposes that the management can overcome this problem by linking some incentives (e.g. financial incentives) for the CEO with the long-term performance of the firm because this will motivate the CEO to perform well, because his own financial interest is attached to the performance of the firm. It is also important to note that, the turnover of CEO is negatively associated with firm performance because the shareholders lose confidence in these firms and stop making more investments and thus making the tenure of a CEO, an important determinant of the firm's performance.

\subsubsection{Management Equity Holding}

According to Iskandar et al (2011), the higher the proportion of the management equity ownership, the better in terms of the going concern of a firm as the management would do anything legally possible to protect not only their economic interests but also the general economic interests of the entire shareholders. Larcker and Tayan (2011) argue that executives who hold equity in the companies they manage, have greater incentive to build the firm's economic value. Equity ownership discourages self-interested behavior because actions that impair firm value would inflict corresponding damage to the executive's personal wealth. As such, equity ownership by the management is expected to mitigate agency problems.

\subsection{Dividend Payout}

Dividend payout (DPY) refers to the proportion of total profit paid out to ordinary shareholders as dividends. DPY is defined by Hellstrom and Inagambaev (2012) as the percentage of the company's earnings that is distributed to shareholders. Dividend payout is the amount of dividend that is paid to shareholders of a firm. Large dividend payout in a period would reduce funds available for investment in subsequent periods and that would lead to the tendency of raising equity or debt in the next period to finance investment. On the other hand, large investment outlay would lead to a reduction in available funds to finance dividend payout and increase the need for external debt financing during the next period to finance dividend payment (Fumey and Doku, 2013).

According to Khan and Ashraf (2014), dividend payout 
ratio decision is due consideration for its legal and financial factors. Managers should consider determinants in deciding amount and size of cash distribution for shareholders. The determinants that may affect dividend payout ratio include corporate profitability, cash flow, tax, debt to equity ratio and sales growth. The practice that management follows in making dividend payout decisions is known as dividend policy (Lease et al, 2000). Dividend decisions are important because they determine what funds flow to investors and what funds the firm retains for investment (Ross et al., 2002). More so, they provide information to stakeholders concerning the company's performance.

\subsection{Empirical Review}

Mwangi (2013) conducted a study on the effect of corporate governance on financial performance of companies listed at Nairobi Security Exchange using a population of all those companies which were quoted on the Nairobi Securities Exchange as at December 2012. The study examined board size, board composition, CEO duality and leverage, and how they affect the financial performance of listed Companies at NSE. Firm performance was measured using Return on Assets (ROA) and Return on Equity (ROE). The study found that a strong relationship exist between the Corporate Governance practices under study and the firms' financial performance. There was a positive relationship between board composition and firm financial performance. Similarly, leverage was found to positively affect financial performance of the studied firms. On CEO duality, the study found that separation of the role of CEO and the chairperson positively influenced the financial performance of listed firms.

Shisia et al (2014) carried out a study to find out the effect of dividend policy on financial performance of companies quoted at the Nairobi Securities Exchange (NSE) for the period 2001-2011. Using a sample of 30 listed companies, a regression relationship was generated to show the extent to which each independent variable influenced the dependent variable. A correlation analysis was also performed to find how the variables were related to each other in the model. The study concluded that there is a significant relationship between dividend payout ratio and dividend per share. There was further indication that the relationship is not only significant but also direct such that a unit change in dividend per share is followed by a unit positive change in retained earnings. The study also found out that the performance of returns on equity is higher than the performance of all the other variables as given in the trends.

Kamau and Basweti (2013) investigated the relationship between corporate governance and working capital management efficiency of firms listed at the Nairobi Securities Exchange. They used a population of all the forty two (42) firms which had been consistently listed at the Nairobi Securities Exchange from 2006-2012. The data for the study was collected from secondary sources. Independent one-way ANOVA test and independent t-tests were conducted in order to determine the level of significance of the relationship between the two variables. The study results indicated that there was no statistical significant relationship between corporate governance and working capital management efficiency.

Kurawa and Ishaku (2014) investigated the effect of corporate governance on dividend policy of five commercial banks out of the fifteen that were listed on the Nigerian Stock Exchange over the period of 2003-2012. The results revealed that management equity holding has significant effect on dividend payout ratio; Board size and CEO duality had insignificant effect, while board independence exhibited negative but insignificant effect. They recommended that since the fundamental purpose of any company is the creation and delivery of long-term sustainable value in a manner consistent with their obligations as a responsible corporate citizen, then the Bank should therefore view corporate governance not as an end in itself but a vital facilitator to the creation of long- term value for all stakeholders. Further, they suggested that to enhance the level of influence of Corporate Governance on Dividend Payout Ratio to higher level in the Nigerian Banking Industry, Management equity holding should be increased as this will make the management to protect not only their interest but also the interest of all stakeholders.

\section{Research Methodology}

\subsection{Research Design and Target Population}

This study used a correlational research design. The population was made up of all the manufacturing companies, that were consistently listed at the NSE from 2008-2014.

\subsection{Data Collection and Data Analysis}

Secondary data for a period of seven (7) years, (2008-2014), was collected from audited annual reports of the companies. The data collected was coded and analyzed using SPSS (statistical package for social sciences). Correlational analysis was used to test the relationship between each corporate governance variable and dividend payout. Regression analysis was used to test the strength of the relationship between the independent variables relating to corporate governance and dependent variable (dividend payout). Correlation of coefficient value greater than 0.5 irrespective of the sign indicated a strong relationship, whereas value below 0.5 showed weak relationship between the variables. One tailed t-test and ANOVA (Analysis of Variance) test was used to test the degree of relationship between the variables. Values greater than 0.05 indicated statistically insignificant impact, while values less than 0.05 indicated statistically significant impact. The regression model that was used can be expressed as follows;

$$
\begin{gathered}
\mathrm{Y}_{\mathrm{it}}=\beta \mathrm{o}+\beta 1 \mathrm{BOS}+\beta 2 \mathrm{BOC}+\beta 3 \mathrm{CEOT}+\beta 4 \mathrm{MGTEQHOL}+ \\
\beta 5 \mathrm{FS}+\beta 6 \mathrm{FP}+\mathrm{e}_{\mathrm{t}}
\end{gathered}
$$

Where;

Yit - DPY for manufacturing firms at time $\mathrm{t}$

Bo - Y-intercept 
BOS - Board Size (Logarithm of the number of directors serving in the board)

BOC - Board Composition (ratio of outside directors to the total number of directors)

CEOT - CEO Tenure (logarithm of the number of years served by the CEO)

MGTEQHOL - Management Equity Holding, (measured by the proportion / percentage of equity ownership of the company directors)

FS and FP - Firm size (logarithm of average assets of firm) and Firm profitability (Ratio of net income after tax to sales revenue), which are both used as control variables in the model

$e_{t}$ - error term which account for other possible factors that could influenceYit that are not captured in the model

\section{Results and Discussion}

\subsection{Correlation Analysis}

Table 1. Correlation analysis and test of significance.

\begin{tabular}{|c|c|c|c|c|c|c|c|c|}
\hline \multicolumn{9}{|c|}{ Correlations } \\
\hline & & BOC & BOS & CEOT & МЕН & DPY & FS & FP \\
\hline \multirow{2}{*}{$\mathrm{BOC}$} & Pearson Correlation & 1 & .341 & $-.432^{*}$ & $-.573^{* *}$ & -.101 & .200 & .014 \\
\hline & Sig. (1-tailed) & & .090 & .042 & .008 & .350 & .221 & .479 \\
\hline \multirow{2}{*}{ BOS } & Pearson Correlation & & 1 & -.197 & -.098 & $.432^{*}$ & $.961^{* *}$ & -.266 \\
\hline & Sig. (1-tailed) & & & .225 & .355 & .041 & .000 & .151 \\
\hline \multirow{2}{*}{ CEOT } & Pearson Correlation & & & 1 & $.495^{*}$ & -.328 & -.088 & -.237 \\
\hline & Sig. (1-tailed) & & & & .022 & .099 & .369 & .180 \\
\hline \multirow{2}{*}{ MEH } & Pearson Correlation & & & & 1 & -.190 & -.050 & -.105 \\
\hline & Sig. (1-tailed) & & & & & .232 & .425 & .345 \\
\hline \multirow{2}{*}{ DPY } & Pearson Correlation & & & & & 1 & $.450^{*}$ & .051 \\
\hline & Sig. (1-tailed) & & & & & & .035 & .422 \\
\hline \multirow{2}{*}{ FS } & Pearson Correlation & & & & & & 1 & -.246 \\
\hline & Sig. (1-tailed) & & & & & & & .170 \\
\hline FP & $\begin{array}{l}\text { Pearson Correlation } \\
\text { Sig. (1-tailed) }\end{array}$ & & & & & & & 1 \\
\hline
\end{tabular}

*. Correlation is significant at the 0.05 level (1-tailed).

**. Correlation is significant at the 0.01 level (1-tailed).

According to the results in table 1, the Pearson's value on the relationship between board size and dividend payout was -0.432 . This indicates that there exists a negative and a weak relationship between the two variables implying that an increase in board size reduces the dividend payout. The significance value of the relationship between the two variables was 0.041 and this signifies that board size has a statistical significant impact on dividend payout. Based on these findings, the study rejects the first hypothesis and concludes that board size has a statistical significant impact on dividend payout of manufacturing firms listed at the NSE for the period 2008 to 2014 . This is consistent with findings by Raheja (2005) who found board size to have a significant impact on dividend payout.

The results in table 1 show that board composition and dividend payout have a weak negative relationship as evidenced by the low Pearson's value of -0.101 . The one tailed significant value was 0.350 and this shows that board composition has no statistical significant impact on dividend payout because $0.350>0.05$. Therefore, the study fails to reject the second hypothesis and concludes that, board composition has no statistical impact on the dividend payout of manufacturing firms listed at the NSE for the period 2008-2014. These findings are similar to Kurawa and Ishaku
(2014) who found that board composition has negative and insignificant effects on dividend payout ratio.

Table 1 show that the correlation coefficient value between CEO tenure and dividend payout was -0.328 . The low negative correlation value implies that the two variables have a weak negative relationship. This suggests that an increase in CEO tenure reduces the dividend payout. However, the one tailed significant value of 0.099 implies that the CEO tenure had statistically insignificant impact on dividend payout. Based on these findings, the study fails to reject the third hypothesis and concludes that, CEO tenure has no statistical significant impact on dividend payout of manufacturing firms listed at the NSE for the period 2008-2014.

According to table 1 above, management equity holding and dividend payout were found to have a weak negative relationship based on the correlation coefficient value of -0.190 . This suggests that an increase in management equity holding reduces the dividend payout. The one tailed significant value of 0.232 implies that management equity holding had no statistical significant impact on dividend payout of the manufacturing firms that were studied. Therefore, the study fails to reject the fourth hypothesis and concludes that, management equity holding has no statistical 
impact on dividend payout of manufacturing firms listed at the NSE for the' period 2008-2014. However, this is in contrast to a study by Ada (2012) that found that management equity holding is positively related to dividend payout and that it has a statistical significant impact on dividend payout.

\subsection{Regression Analysis}

Table 2. Multiple Regression analysis.

\begin{tabular}{|c|c|c|c|c|c|c|c|c|c|c|}
\hline \multicolumn{11}{|c|}{ Model Summary } \\
\hline \multirow{2}{*}{ Model } & \multirow{2}{*}{$\mathbf{R}$} & \multirow{2}{*}{ R Square } & \multirow{2}{*}{$\begin{array}{l}\text { Adjusted R } \\
\text { Square }\end{array}$} & \multirow{2}{*}{$\begin{array}{l}\text { Std. Error of } \\
\text { the Estimate }\end{array}$} & \multicolumn{5}{|l|}{ Change Statistics } & \multirow{2}{*}{ Durbin-Watson } \\
\hline & & & & & R Square Change & F Change & df1 & df2 & Sig. F Change & \\
\hline 1 & $.692^{\mathrm{a}}$ & .478 & .401 & .231102 & .478 & 1.529 & 6 & 10 & .263 & 2.407 \\
\hline
\end{tabular}

a. Predictors: (Constant), FP, BOC, FS, CEOT, MEH, BOS

b. Dependent Variable: DPY

According to table 2 above, the correlation coefficient (R) value was 0.692 . This means that there is a strong relationship between corporate governance and dividend payout $(r>0.5)$. However, table 2 indicates that corporate governance explains only $47.8 \%$ of the differences in dividend payout as shown by the coefficient of determination value $\left(\mathrm{R}^{2}\right)$ of 0.478 . Moreover, the significance value of 0.263 implies that corporate governance cannot be used to adequately predict changes in dividend payout because $\mathrm{P}>$ 0.05 . This implies that corporate governance has no statistical significant impact on dividend payout. The Durbin-Watson measure of autocorrelation in this analysis was 2.407. This signifies that there was no autocorrelation among the independent variables due to the fact that it was within the acceptable levels of 1.5 to 2.5 .

\subsection{Test of Hypothesis}

Table 3. ANOVA test.

\begin{tabular}{lllllll}
\hline ANOVA $^{\mathrm{a}}$ & & & & & \\
\hline Model & & Sum of Squares & Df & Mean Square & F \\
\hline \multirow{3}{*}{1} & Regression & .490 & 6 & .082 & 1.529 \\
& Residual & .534 & 10 & .053 & \\
& Total & 1.024 & 16 & & \\
\hline
\end{tabular}

a. Dependent Variable: DPY

b. Predictors: (Constant), FP, BOC, FS, CEOT, MEH, BOS

According to table 3 above, the overall significance of the model was 0.263 with an $F$ value of 1.529 . The level of significance was higher than 0.05 and this means that corporate governance practices do not have a statistical significant impact on dividend payout. Therefore, this study fails to reject the null hypothesis and concludes that corporate governance has no statistical impact on dividend payout of manufacturing firms listed at the NSE for the period 2008-2014.

Table 4. Regression Coefficients.

\begin{tabular}{|c|c|c|c|c|c|c|c|c|}
\hline \multicolumn{9}{|c|}{ Coefficients $^{\mathrm{a}}$} \\
\hline \multirow{2}{*}{\multicolumn{2}{|c|}{ Model }} & \multicolumn{2}{|c|}{ Unstandardized Coefficients } & \multirow{2}{*}{$\begin{array}{l}\text { Standardized Coefficients } \\
\text { Beta }\end{array}$} & \multirow{2}{*}{$\mathbf{T}$} & \multirow{2}{*}{ Sig. } & \multicolumn{2}{|c|}{ 95.0\% Confidence Interval for B } \\
\hline & & B & Std. Error & & & & Lower Bound & Upper Bound \\
\hline \multirow{7}{*}{1} & (Constant) & .669 & 1.451 & & .461 & .655 & -2.565 & 3.902 \\
\hline & $\mathrm{BOC}$ & -1.105 & .611 & -.622 & -1.808 & .101 & -2.467 & .257 \\
\hline & BOS & .799 & 1.428 & .616 & 3.559 & .034 & -2.384 & 3.981 \\
\hline & CEOT & -.276 & .289 & -.286 & -.954 & .362 & -.921 & .369 \\
\hline & MEH & -.006 & .005 & -.335 & -1.074 & .308 & -.017 & .006 \\
\hline & FS & -.011 & .357 & -.031 & -.030 & .977 & -.807 & .786 \\
\hline & FP & 233 & .520 & .114 & .448 & .664 & -.925 & 1.391 \\
\hline
\end{tabular}

a. Dependent Variable: DPY

According to table 4 above, the significance of board size in explaining changes in dividend payout among the manufacturing firms that were included in the study was 0.034. This indicates that board size has statistically insignificant impact on dividend payout $(p<0.05)$. The $t$ value of 3.559 is above the acceptable level of 3 and this further signifies that the impact of board size on dividend payout was statistically significant. The significance of board composition in explaining changes in dividend payout among the manufacturing firms that were included in the study was 
0.101 . This indicates that board composition has statistically insignificant impact on dividend payout $(p>0.05)$. The t value of -1.808 is below the acceptable level of 3 and this further signifies that the impact of board composition on dividend payout was not statistically significant. Similarly, the significance level of CEO tenure was 0.362 which is more than the acceptable level of 0.05. This implies that CEO tenure has no statistical significant impact on dividend payout of manufacturing firms listed at the NSE. The data further indicates that management equity holding has no statistical significant impact on dividend payout based on the significance value of 0.308 . Moreover, their $t$ values of -0.954 and -1.074 were less than 3 thereby implying that they could not be used to adequately explain changes in dividend payout.

\section{Summary}

The aim of the study was to evaluate the impact of corporate governance on dividend payout of manufacturing firms listed at the NSE. The results of the correlation analysis indicated that board size, board composition, CEO tenure and management equity holding had a weak negative correlation with dividend payout. Nonetheless, one tailed tests indicated that board composition, CEO tenure and management equity holding did not have a statistical significant impact on dividend payout. On the other hand, the significance value of the relationship between board size and dividend payout was 0.041 and this signifies that board size has a statistical significant impact on dividend payout $(\mathrm{P}<0.05)$. The computed correlation coefficient value was 0.692 which indicated that there is a strong relationship between corporate governance and dividend payout $(r>0.5)$. However, the significance value of 0.263 implies that corporate governance cannot be used to adequately predict changes in dividend payout $(\mathrm{P}>0.05)$. This implies that corporate governance has no statistical significant impact on dividend payout of manufacturing firms.

\section{References}

[1] Abdel-Halim, M. \& Bino, A. (2009). Corporate Governance and Dividend Policy: An Empirical Investigation of Jordanian Non-Financial Corporations. New Delhi, McGraw Hill Education (India) Private Ltd.

[2] Achchuthan, S. and Kajananthan, R., (2013). Corporate Governance practices and Working Capital Management Efficiency, Journal of Financial Economics, 77, 19-27.

[3] Ada, B. A., (2012). The Relationship between corporate governance practices and dividend payout of commercial banks in Kenya. International Journal of Academic Research in Accounting, Finance and Management Sciences 4, 11-90.

[4] Adjaoud, F. and Amar, W. (2011). Corporate Governance and Dividend Policy. Journal of Business Finance \& Accounting, 37, 648-667.
[5] Ajanthan, A. (2013) Corporate Governance And Dividend Policy: A Study Of Listed Hotels And Restaurant. International Journal of Management in Education 3, 7-27.

[6] Calder, A. (2011). Corporate Governance: A Practical Guide to the Legal frameworks and International Codes of Practice. Mason, South Western Cengage publishers.

[7] Chung, K., Elder, J., \& Kim, J. (2010). Corporate Governance and Liquidity. Journal of Financial and Quantitative Analysis, $45,265-291$.

[8] Dalton, D., Daily, C., Ellstrand, A., \& Johnson, J. (2009). Number of directors and financial performance. The Academy of Management Journal, 42, 674-686.

[9] Fumey, A. and Doku I., (2013). Dividend payout ratio in Ghana: Does the pecking order theory hold good? Journal of Emerging Issues in Economics, Finance and Banking, 2, 14-45.

[10] Griffin, C. (2010). Liquidity and Dividend Policy: International Evidence. International Business Research, 3, 3-9.

[11] Gul, S., Sajid, M., Razzaq, N., Iqbal, M., \& khan, M.(2012). The Relationship between Dividend Policy and Shareholders Wealth: Evidence from Pakistan. Economics and Finance Review, 2, 55-59.

[12] Hamdouni, A. (2012). Dividend Policy and Corporate Governance in Saudi Stock Market. Archives Des Sciences Journal, 65, 24-26.

[13] Hassan, A. (2010). Corporate governance and dividend policy in Kenya. International Journal of Academic Research in Accounting, Finance and Management Sciences, 4, 15-20.

[14] Heinrich, R. (2002). Complementaries in Corporate Governance. New York, Springer science \& business media publishers.

[15] Hellstrom, G., \& Inagambaev, G. (2012) Determinants of Dividend Payout Ratios, A Study of Swedish Large and Medium Caps. Journal of Emerging Issues in Economics, Finance and Banking (JEIEFB), 2, 52-65.

[16] Hifzalnam, P., \& Mukhtar, A. (2014). Corporate Governance and Its Impact on Performance of BankingSector in Pakistan. International Journal of Information, Business and Management, 6, 106-117.

[17] Iskandar, R., Rahmat, Noor, A., Saleh, M. \& Ali, M. (2011). Corporate governance and going concern problems. International Journal for Corporate Governance, 2 (2), 119-139.

[18] Kamau, M., \& Basweti, K., (2013). The relationship between Corporate Governance and Working Capital Management Efficiency of Firms Listed at the Nairobi Securities Exchange. Journal of Finance and Accounting, 4, 102-110.

[19] Khan, W. \& Ashraf, N., (2014). In Pakistani Service Industry: Dividend Payout Ratio as Function of some Factors, International Journal of Academic Research in Accounting, Finance and Management Sciences 4, 13-33.

[20] Kurawa, J. \& Ishaku, A., (2014). The effect of corporate governance on dividend policy of listed banks in Nigeria. Journal of Business Finance \& Accounting, 37, 15-45.

[21] Larcker, D. \& Tayan, B. (2011). Corporate Governance Matters. Journal of Emerging Issues in Economics, Finance and Banking, 2, 32-52. 
[22] Lease, R. C., Kose J. A., Uri L., \& Oded H. S., (2000). Dividend Policy: Its impact on firm value. Harvard Business School Press, Boston, Massachusetts.

[23] Mayer F. (2007). Corporate Governance, Competition and Performance, Enterprise and Community.

[24] Mason, South Western Cengage publishers.

[25] Metrick, A. and Ishil, J., (2002). Corporate Governance and Equity Prices. Quarterly Journal of Economics, 113, 653-691.

[26] Murekefu, T., \& Ouma, O, (2010). The Relationship between Dividend Payout and Firm Performance. European Scientific Journal, 8, 199-215.

[27] Mwangi, M., (2013). The Effect of Corporate Governance on Financial Performance of Companies Listed at Nairobi Security Exchange. International Journal of Commerce and Management Research, 2, 54-82.

[28] Ongore, V., and K'Obonyo, P. (2011). Effects of selected corporate governance on firm performance. International Journal of Economics and Financial Issues, 1, 99-122.

[29] Oskar, K., Ivan, K. \& Oleksandr, T. (2007). Does corporate governance affect dividend policy? Warsaw School of Economics, World Economy Research Institute, Al. Niepodlegosci 162, 02-554.

[30] Raheja, C. (2005). Determinants of board size and composition: A theory of corporate boards. Journal of Financial and Quantitative Analysis, 40, 283-306.

[31] Ramdani, D., \& Van, W. (2009). Board independence, CEO duality and firm performance: A quantile regression analysis for Indonesia, Malaysia, South Korea and Thailand. University of Antwerp Press.
[32] Rani, D., and Mishra, R., (2008). Corporate Governance. New Delhi, Excel Publishers.

[33] Ross, S., Westerfield, R. \& Jaffe, J. (2002). Corporate Finance (6th ed.). McGraw-Hill Companies.

[34] Sheikh, N., \& Wang, Z. (2012). Effects of Corporate Governance on Capital Structure: Global Disclosure of Economics and Business Journal 12, 629-641.

[35] Shisia, A., Sang W., Sirma K., and Maundu C. N, (2014). Assessment of dividend policy on financial performance of telecommunication companies quoted at the Nairobi securities exchange. European Scientific Journal, 8, 21-69.

[36] Valenti, A., Luce, R., \& Mayfield, C. (2011). The Effects of Firm Performance on Corporate Governance. Management Research Review, 34, 266-283.

[37] Vives, X., (2000). Corporate governance. Cambridge, Cambridge University Press.

[38] Vojtech, C. (2013). The Relationship between Information Asymmetry and Dividend Policy. Charleston, BiblioBazaar publishers.

[39] Wanyonyi, D. and Olweny, T. (2013). Effects of Corporate Governance on Financial Performance of Listed Insurance Firms in Kenya. International Journal of Commerce and Management Research, 2, 44-81.

[40] Yocam, E., and Choi, A. (2010). Corporate Governance: A Board Director's Pocket Guide Leadership, Diligence and Wisdom. New York, Pearson publishers.

[41] Yusoff, W. \& Alhaji I., (2012). Corporate Governance and Firm Performance of listed Companies in Malaysia. European Journal of Commerce and Management Research, 2, 43-65. 